\title{
Fiscal Policy in Emerging Economies Romania, Poland, Hungary, Czech Republic
}

The Bucharest University of Economic Studies

E-mail: iulia.rosoiu@yahoo.com

\begin{abstract}
The aim of this article is to examine the impact of domestic fiscal shocks on output in Romania, Poland, Hungary and Czech Republic over the period 1995-2020. All countries are European Union's members which didn't adopt yet euro currency. Vector autoregression models are used and the results show that fiscal policy has positive or negative effects on economic growth. For all countries included in the analysis the magnitude of the impact is small.
\end{abstract}

Keywords: economic growth, fiscal shocks, emerging economies, VAR model

JEL Classification: E62, H20, H50

DOI : 10.24818/RMCI.2019.3.279

\section{Introduction}

It is important to analyze the impact of the government expenditures and revenues on the economic growth because the state uses fiscal policy as an instrument for controlling the economy development. This article wants to contribute to the analysis of the emerging countries and in the same time to compare the magnitude of the fiscal policy effects within a group of homogeneous countries. Estimating a VAR model, the results will show whether it is more important to control the government expenditures, the government revenues or both variables should be taken into consideration at the same time.

The main question is: would it be better to adopt a restrictive fiscal policy (it means to decrease the government expenditures and to increase the government revenues - taxes) or an expansive fiscal policy (it means to increase the government expenditures and to decrease the government revenues - taxes) in order to determine economy growth?

Section 2 presents conclusions described by other economic analysts. Section 3 explains the econometric methodology used and variables transformations. Section 4 presents the results of the estimation and section 6 summarize the findings.

\footnotetext{
${ }^{1}$ Iulia ROȘOIU, The Bucharest University of Economic Studies,

E-mail: iulia.rosoiu@yahoo.com
} 


\section{Related literature}

Most studies focusing on fiscal policy consider advanced economies, however, hereunder, there are presented analysis focusing on emerging economies from Central and Eastern Europe. The results obtained by other authors will help with validating the findings of this paper. The period considered and the econometric methodology used are different.

Romer and Romer (2010) have analyzed the role of fiscal policy and they concluded that governments use it as an instrument for driving the economy in the needed directions. Decisions linked to fiscal policy are being made in order to generate economic growth, to finance the budget deficit or lower the negative impact of internal and external factors which affect the economic growth.

Klyuev and Snudden (2011) found the impulse response of output gap to a shock of government expenditures reached $-0,4$ and to a shock of government revenues $-0,02$ for Czech Republic.

Cuaresma et All (2011) estimated fiscal policy shock for five Central and Ester European countries (Slovenia, Slovakia, Poland, Hungary and Czech Republic) over the period 1995-2009 using a structural vector autoregressive model. Domestic spending shock is significative in all countries, except Slovenia. The effect on growth is negative in Czech Republic, Poland and Slovakia and it is positive in Hungary. Domestic taxation shock is significative in all countries, except Hungary. The effect on growth is negative in Slovakia and it is positive in Czech Republic, Poland and Slovenia. They concluded that impulse response of economic growth range between $-0,04$ and 0,01 for a government expenditure shock and between $-0,1$ and 0,03 for a government revenue shock.

Costache (2017) has analyzed the impact of fiscal policy on economic growth for Romania, Poland, Hungary and Bulgaria using trimestral data, over the period 1999-2016. A structural break was considered in 2009, justified by the intention of the author of considering the effects of financial crisis on the economic growth. Several variables were included in the models estimated, not only fiscal variables, however for the purpose of this paper, it is important to note the general positive effect of fiscal instruments on economic growth in all countries.

Muir and Weber (2013) quantified fiscal multipliers for Bulgaria using vector autoregression methodology and as variables real GDP, real net revenues (total revenues minus transfers, subsides and interest payments) and real net expenditures (government consumption and investment). Periods considered for the analysis is 1999-2011, with quarterly data, 2003-2011, with monthly data and 2003-2006, with monthly data. The results show that fiscal multipliers are significant and positive for revenues and expenditure only over the period 2003-2006, meaning that positive effects on growth can be noticed during rise in spending and cut in taxes.

\section{Econometric methodology and data used}

In order to analyze the impact of government expenditures and revenues on the economic growth, VAR model framework is used (Brooks, C., 2002). The standard model used for VAR analysis is described in the equation (1):

$280 \quad$ Volume 20, Issue 3, July $2019 \quad$ Review of International Comparative Management 


$$
\mathrm{Y}_{\mathrm{t}}=\mathrm{A}(\mathrm{L})^{*} \mathrm{Y}_{\mathrm{t}-1}+\mathrm{B}(\mathrm{L}) * \mathrm{X}_{\mathrm{t}}+\varepsilon_{\mathrm{t}}
$$

where:

- $\mathrm{Y}_{\mathrm{t}}$ - the endogenous variables vector;

- $\mathrm{X}_{\mathrm{t}}$ - the exogenous variables vector;

- $\varepsilon_{\mathrm{t}}$ - the errors vector;

- $\mathrm{A}(\mathrm{L})$ and $\mathrm{B}(\mathrm{L})$ - the coefficients of the endogenous and exogenous variables vector.

The purpose of the study is to analyze the domestic fiscal shock; therefore the exogenous variables vector is not used. This approach will help with understanding the role of government in controlling economy growth in Romania, Poland, Hungary and Czech Republic. This paper focuses on how fiscal and budged policies are used in these countries.

In order to analysis the impact of the government expenditure and revenues on economic growth in Romania, Poland, Hungary and Czech Republic, annual data over the period 1995-2020 is being used published by AMECO database (with predicted values for 2019 and 2020). Real GDP growth rate is used as proxy for economic growth. Fiscal and budget variables are considered as percentage of GDP.

Figure 1, hereunder, shows the evolution of the real GDP growth rate for the four countries included in the analysis. Poland is the one which registered a constant rate growth, even during economic crisis. Negotiations for becoming an European Union members states took place in 2000. Before this year, Romania was registering the smallest growth rate, even negative, and Hungary the highest one. These countries have been preparing for reaching the minimum economic criteria's for being accepted by the European Union. During the period 2000-2006, most of these countries continue to growth constantly, except Romania, which managed to diminish the growth rate gap and even to overcome the other countries. Economic crisis impacted differently these countries: Poland followed same economic growth path, Romania, Hungary and Czech Republic registered negative growth rate, 2009 being the year when the negative growth rates were the smallest. Starting with 2012, these three countries have been recovering from the damage caused by the economic crisis.

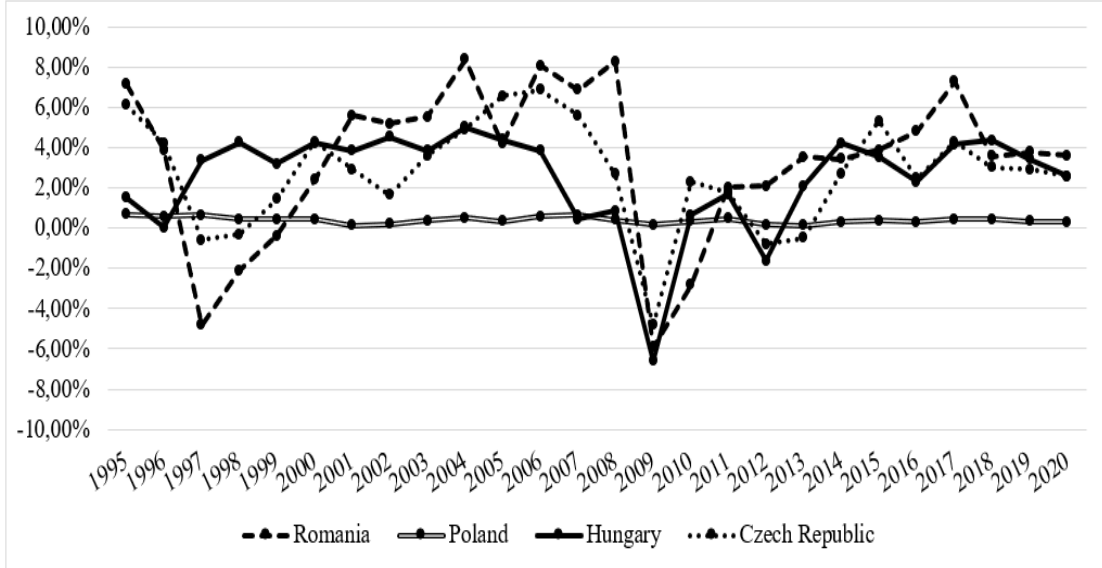

Figure 1. Evolution of real GDP growth rate

Source: authors' estimations based on AMECO database (2019, 2020 - predicted values) 
Since annual data is considered, it is not necessary to analyze the three series in terms of seasonality. Seasonal adjustment can only be applied on series with a frequency lower than one year: daily, weekly, monthly, quarterly data. The analysis starts by applying Hodrick-Prescott filter, having the purpose of correcting the trend of the series. Only government expenditure variable for Hungary was de-trended.

Augmented Dickey Fuller (ADF) test and Kwiatkowski-Phillips-SchmidtShin (KPSS) test are used in order to verify if variables are stationary or not. These tests indicate if variables are not stationary and it is needed to be differentiated once in order to become stationary. The null hypothesis of the ADF test characterizes the series as non-stationary or unit root process. This hypothesis is accepted if p-value associated to the statistic of the test is higher than 5\%. The results show that government expenditures for Hungary is not stationary and thus it was differentiated once.

Table 1, hereunder, explains the variables notations used estimating the VAR models.

Table 1. Variables notations used in the analysis

\begin{tabular}{cl}
\hline Notations & $\begin{array}{l}\text { Variables } \\
\text { (not seasonally adjusted data) }\end{array}$ \\
\hline Rata-PIB & Real GDP growth rate \\
\hline CH-BUG & Total government expenditures \\
\hline V-BUG & Total government revenue \\
\hline
\end{tabular}

Note: "T" at the end of variable notation - variables for which Hodrick-Prescott filter was applied with the purpose of removing the trend from the series;

"DIF" at the end of variable notation - variables that are integrated at first order and were differentiated once in order to become stationary.

The VAR model contains real GDP growth rate, government expenditures and government revenues. VAR models are estimated using variables transformed as explained above (when needed they were de-trended or differentiated). The form of the VAR model can be written as in equation (2):

$$
Y_{t}=[\text { rata_PIB }, \text { ch_bug }, \text {, v_bug } t] \text {. }
$$

The results of the VAR models estimated are interpreted using the impulse response function, which shows the dependent variable evolution when independent variables receive individually a shock. It is preferable that the shock disappears over time in order to affirm that the model is stable.

\section{Results of the VAR models estimated}

This section presents the economic growth responses to domestic fiscal policy shocks for each country considered for the analysis. The impulse responses of the economic growth determined first by a shock into government expensive (a) and afterwards by a shock into government revenues (b) are shown in figure 2 for Romania, figure 3 for Poland, figure 4 for Hungary and figure 5 for Czech Republic.

$282 \quad$ Volume 20, Issue 3, July $2019 \quad$ Review of International Comparative Management 
The results show weak response of the real GDP growth rate in either of the cases, domestic government expenditures and revenues shocks.

A shock into government expenditure determines a decrease of the economic growth, while a shock into government revenues has a positive effect on the economic growth, as it is shown in figure 2 for Romania. However, in both cases the magnitude is small. The impulse response of the real GDP real growth rate to a government expenditure shock stands at -1 , after 3 years and to a government revenue shock is 2 , after one year.

Response to Cholesky One S.D. Innovations \pm 2 S.E.
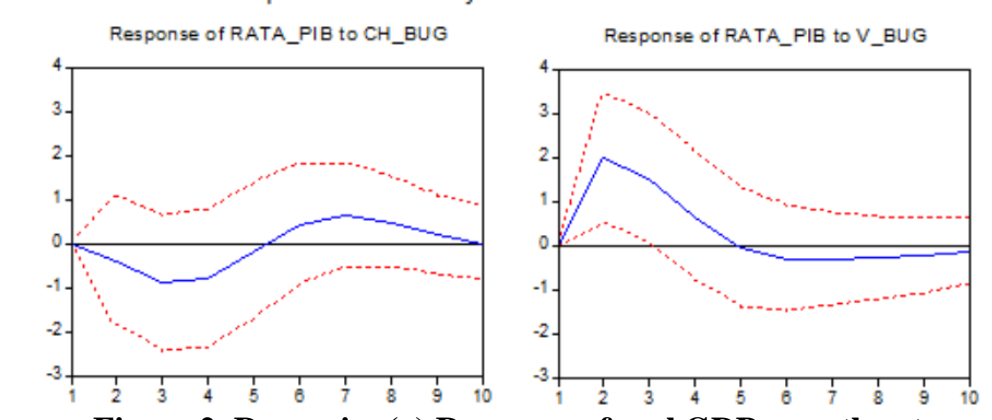

Figure 2. Romania: (a) Response of real GDP growth rate to government expenses shock;

(b) Response of real GDP growth rate to government revenues shock;

Source: authors' estimations based on AMECO database (2019, 2020 - predicted values)

A shock into government expenditure and the shock into government revenues have a positive impact on the economic growth, as it is shown in figure 3 for Poland. The effects are even small than in Romania and they are noticed for two periods. The impulse response of the real GDP real growth rate to a government expenditure shock stands at 0,04 and to a government revenue shock is $-0,02$, after one year.

Response to Cholesky One S.D. Innovations \pm 2 S.E.
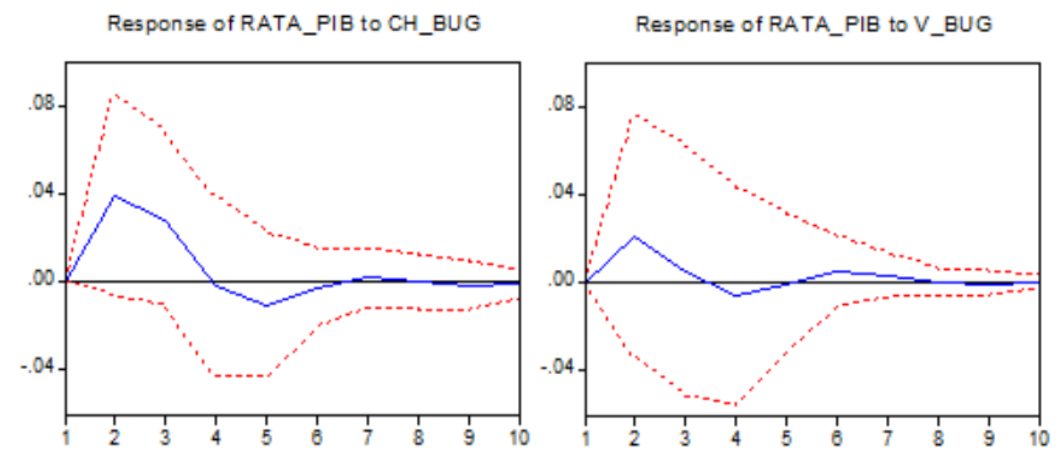

Figure 3. Poland: (a) Response of real GDP growth rate to government expenses shock;

(b) Response of real GDP growth rate to government revenues shock;

Source: authors' estimations based on AMECO database (2019, 2020 - predicted values) 
A shock into government expenditure and the shock into government revenues have a negative and not significative impact on the economic growth, as it is shown in figure 4 for Hungary. The impulse response of the real GDP real growth rate to a government expenditure shock stands at $-0,2$ and to a government revenue shock is $-0,1$, after one year.

Response to Cholesky One S.D. Innovations \pm 2 S.E.
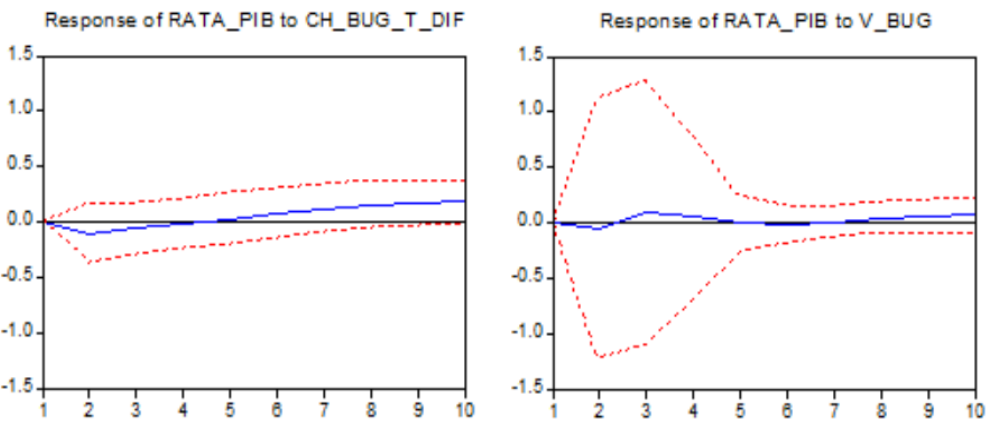

Figure 4. Hungary: (a) Response of real GDP growth rate to government expenses shock;

(b) Response of real GDP growth rate to government revenues shock;

Source: authors' estimations based on AMECO database (2019, 2020 - predicted values)

A shock into government expenditure determines an increase of the economic growth in the first three periods, while a shock into government revenues has a negative impact on the economic growth, as it is shown in figure 5 for Czech Republic. In both cases the effects are not significant. The impulse response of the real GDP real growth rate to a government expenditure shock stands at 0,6 and to a government revenue shock is $-0,4$, after one year.

Response to Cholesky One S.D. Innovations \pm 2 S.E.
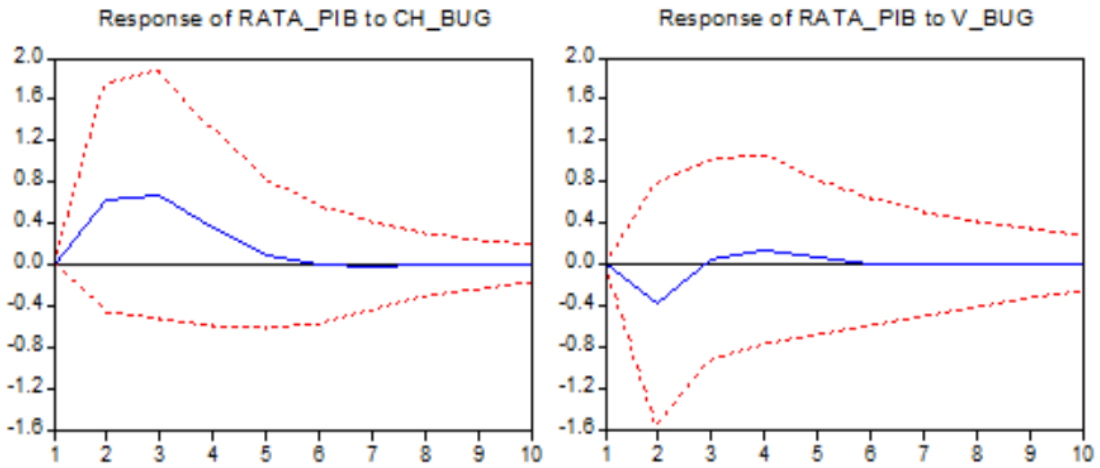

Figure 5. Czech Republic: (a) Response of real GDP growth rate to government expenses shock;

(b) Response of real GDP growth rate to government revenues shock;

Source: authors' estimations based on AMECO database (2019, 2020 - predicted values) 


\section{Conclusion}

The paper is focusing on analyzing the magnitude of the fiscal policy impact on economic growth for four emerging countries: Romania, Poland, Hungary and Czech Republic. The results obtained are different even if these countries are homogenous. Also the economic literature presents different effects of the fiscal instruments on economic growth depending on the period and country considered for the analysis and econometric methodology applied.

The results show weak impulse responses of the real GDP growth rate to the domestic fiscal shocks. Fiscal instruments have the weakest effects in Poland followed by Hungary and Czech Republic. The effects are more important in Romania.

Same small fiscal multipliers were presented also by other authors interested in analyzing emerging countries.

\section{References}

1. Brooks, C., 2002. Introductory econometrics for finance. Cambridge University Press

2. Costache, B., 2017. Cum contribuie politica fiscală la creșterea economică?. ABC-ul Lumii Financiare, WP nr. 5/2017

3. Cuaresma, J., Eller, M., Mehhrota, A., 2011. The economic transmission of fiscal policy shocks from western to eastern Europe. Austrian Central Bank, issue 2

4. Klyuev, V., Snudden, S., 2011. Effects of fiscal consolidation in the Czech Republic. IMF Working paper, no. 65

2. Muir, D., Weber, A., 2013. Fiscal multipliers in Bulgaria: Low, but still relevant. IMF Working paper, no. 49

3. Romer, C., Romer, D., 2010. The Macroeconomic Effects of the Tax Changes: estimates based on a New measure of Fiscal Shocks. American Economic Review 100: 763-801 